\title{
Analisis Koping dan Pertumbuhan Pasca-trauma pada Masyarakat Terpapar Konflik
}

\author{
Marty Mawarpury \\ Fakultas Kedokteran, Universitas Syiah Kuala, Banda Aceh - Indonesia
}

\begin{abstract}
Prolonged conflict in Aceh has caused trauma in people who were directly affected. Aside from post-traumatic disorder, a traumatic event can bring out posttraumatic growth (PTG) too. PTG is a positive transformation that is resulted from an adaptation process of traumatic events in life. This study aimed to examine the relationship between coping and PTG. There were 55 respondents involved in this study, who were obtained by using purposive sampling technique. The sample criteria were those experiencing by themselves certain events during the conflict, men and women over 20 years old, able to read and write, and willing to be respondents for the study. Data were collected using a demographic questionnaire, Post-traumatic Growth Inventory ( $\alpha=$ .88) and Ways of Coping Questionnaire $(\alpha=.89)$. The data were analyzed with the Pearson Product Moment Correlation. The analysis results showed a significant correlation between post-traumatic growth and coping $(r=.523 ; \mathrm{p}<.01)$. In addition, coping ways that correlated with post-traumatic growth were seeking for social support $(\mathrm{r}=.545)$, distancing $(\mathrm{r}=.315)$, self-control and accepting $(\mathrm{r}=.274)$, while confronting and escape did not have a correlation with post-traumatic growth.
\end{abstract}

Keywords: Aceh; community; conflict; coping; post-traumatic growth

\begin{abstract}
Abstrak: Konflik berkepanjangan di Aceh telah mengakibatkan trauma, terutama pada masyarakat yang terpapar konflik langsung. Selain memunculkan gangguan pascatrauma, peristiwa traumatik juga dapat memunculkan pertumbuhan psikologis yang positif pasca-trauma (post-traumatic growth). Pertumbuhan pasca-trauma adalah transformasi positif yang dihasilkan dari proses penyesuaian terhadap peristiwa traumatik dalam hidup. Penelitian ini bertujuan untuk mengetahui hubungan koping dengan pertumbuhan pasca-trauma. Sebanyak 55 responden terlibat dalam penelitian ini yang diperoleh dengan teknik purposive sampling. Adapun kriteria sampel adalah mengalami langsung peristiwa tertentu di masa konflik, laki-laki dan perempuan berusia di atas 20 tahun, dapat membaca dan menulis, dan bersedia untuk menjadi responden. Data dikumpulkan menggunakan kuesioner demografi, post-traumatic growth inventory $(\alpha=$ $0,88)$ dan ways of coping questionnaire $(\alpha=0,89)$. Analisis data menggunakan korelasi product moment Pearson menunjukkan korelasi signifikan antara koping dengan pertumbuhan pasca-trauma $(\mathrm{r}=0,523 ; \mathrm{p}<0,01)$. Selain itu, jenis koping yang berkorelasi dengan pertumbuhan pasca-trauma adalah mencari dukungan sosial $(\mathrm{r}=0,545)$, diikuti oleh distancing $(\mathrm{r}=0,315)$, self control dan accepting $(\mathrm{r}=0,274)$, sedangkan confronting dan escape tidak berhubungan dengan pertumbuhan pasca-trauma.
\end{abstract}

Kata Kunci: Aceh; konflik; koping; masyarakat; pertumbuhan pasca-trauma

Corresponding Author: Marty Mawarpury (e-mail: marty@unsyiah.ac.id). Program Studi Psikologi, Fakultas Kedokteran, Universitas Syiah Kuala Banda Aceh, Jl. Tgk. Tanoh Abee Darussalam Banda Aceh 23111. 


\section{Pendahuluan}

Konflik berkepanjangan di Aceh telah menjadi bagian dari sejarah Indonesia. Berdasarkan laporan Amnesti Internasional, sekitar 35 ribu warga Aceh mengalami pelanggaran hak asasi manusia (HAM). Dugaan pelanggaran yang dimaksud di antaranya hak sipil politik, hak sosial budaya, dugaan pembunuhan dan penyiksaan di luar hukum yang terjadi selama periode konflik. Laporan Komisi Nasional HAM menyebutkan pada masa berlakunya operasi militer (tahun 2000an), sebanyak 781 orang tewas, 163 orang hilang, 386 orang mengalami penganiayaan dan 102 pemerkosaan perempuan. Selain itu, data yang dihimpun Forum Peduli Hak Asasi Manusia terdapat 1.321 korban pembunuhan, 1.958 orang hilang, 3.430 orang mengalami penyiksaan dan 128 orang perempuan mengalami perkosaan (Kontras, 2010).

Di Aceh, eskalasi kekerasan selama konflik mulai menurun setelah dilakukan penandatanganan perjanjian damai di Helsinki pada 15 Agustus 2005, namun dampak konflik masih ada. Salah satunya adalah kondisi mental dan psikososial masyarakat. Konflik selama lebih dari tiga dekade di Aceh, sedikitnya telah menunjukkan adanya dampak pada peningkatan jumlah gangguan mental pada korban konflik, dan gangguan traumatik yang dominan muncul seperti PTSD (post traumatic syndrome disorder) dan trauma komplek yang menjadikan masyarakat rentan dalam menjalani kehidupannya. Perilaku menyerang adalah salah satu wujud respon ketika sesuatu dipandang sebagai ancaman yang diterjemahkan sebagai pertahanan diri namun ternyata telah menjadi pelaku kekerasan berikutnya sebagai akibat menjadi korban kekerasan (Zaini, dalam Mawarpury \& Faisal, 2017).

Hasil penelitian Good, Good, Grayman, dan Lakoma (2006), mencatat sebanyak 5.389 pen- duduk di tiga kabupaten yakni: Pidie, Aceh Utara, dan Bireuen terindikasi mengalami gangguan jiwa akibat konflik tersebut. Ketiga daerah tersebut mengalami eskalasi konflik tertinggi dibandingkan daerah lainnya. Tingkat peristiwa traumatik maupun gejala psikologis berturutturut adalah Pidie 87\%, Aceh Utara 86\%, dan Bireun 66\%. Beberapa temuan terkait kesehatan mental di antaranya: 1) masyarakat mengalami peristiwa traumatik seperti tingginya tingkat kekerasan; 2) masyarakat mengalami kekerasan, namun tingkat dan jenis kekerasan yang dialami berbeda-beda. Laki-laki mengalami kekerasan fisik yang lebih tinggi dibanding perempuan, sedangkan perempuan mengalami kekerasan seksual (meskipun pelaporan rendah disebabkan stigma) dan kekerasan gender; 3) terdapat perbedaan antar daerah terhadap peristiwa traumatik dan gejala psikologis.

Terkait konflik dan proses perdamaian, Aceh menjadi salah satu tempat di Indonesia untuk mempelajari persoalan kemanusiaan (seperti pelanggaran HAM), ekonomi sosial politik, serta kesehatan fisik dan mental. Salah satu yang menjadi ketertarikan peneliti adalah pengalaman yang dialami masyarakat (khususnya yang berada di area eskalasi konflik tinggi) yang dipandang dari sisi positif yaitu pertumbuhan psikologis akibat konflik atau disebut post-traumatic growth. Memahami proses ini menjadi penting dalam upaya menangani implikasi kesehatan psikologis secara individual maupun kolektif pada masyarakat yang terpapar konflik.

Post-traumatic growth (PTG) didefinisikan sebagai perubahan positif yang dialami setelah berjuang dengan kondisi kehidupan yang traumatik. PTG dalam penelitian ini disebut pertumbuhan pasca-trauma. Peristiwa traumatik membutuhkan usaha individu untuk memahami dan memaknai dirinya dan kehidupannya yang berubah akibat peristiwa yang dialami. PTG me- 
miliki tiga domain utama, yaitu: 1) peningkatan hubungan dengan orang lain seperti memiliki nilai yang lebih baik terhadap keluarga dan teman; 2) perubahan pandangan terhadap diri sendiri seperti merasa lebih kuat menghadapi dunia dan memiliki penerimaan lebih besar terhadap keterbatasan diri; 3) perubahan dalam filosofi hidup seperti memberikan apresiasi pada keseharian hidupnya dan bernegosiasi dengan diri dan keadaan (Linley \& Joseph, 2009). Aspekaspek PTG yang dikemukakan Tedeschi dan Calhoun (2004) yaitu: 1) apresiasi yang besar pada hidup, hal ini dicapai dengan memaknai hidup dengan baik setiap harinya, berfokus pada apa yang dimiliki dan menikmatinya; 2) hubungan dekat dengan orang lain. Pada aspek ini, individu lebih mampu mengenali makna hubungan dengan teman dan keluarga, meluangkan lebih banyak waktu dengan orang lain dan meningkatkan kemampuan berempati; 3) kemungkinan baru dalam hidup; 4) peningkatan pertumbuhan pribadi memungkinkan individu miliki kemampuan koping dengan kondisi menekan seperti trauma hingga menumbuhkan self efficacy; 5) perubahan spiritual.

Beberapa faktor yang diidentifikasi berkontribusi pada PTG adalah usia dan jenis kelamin, peristiwa traumatik, kepribadian, koping, dukungan sosial seperti keluarga, teman, dan organisasi. Sejumlah studi telah menunjukkan faktor-faktor yang berhubungan dengan pertumbuhan pascatrauma di antaranya relasi dalam keluarga (Svetina \& Nastran, 2012), daya lenting dan kepribadian tangguh (Almedom, 2005), trauma kesedihan, kehilangan, dan kerugian (Davis, Wohl, \& Verberg, 2007; Gerrish, Dyck, \& Marsh, 2009; Neria \& Litz, 2004), optimis dan koping (Larner \& Blow, 2011; Prati \& Pietrantoni, 2009), peran situasi mencakup tipe dan penilaian dalam koping (Terry, 1994), budaya (Johnson, Thompson, \& Downs, 2009; Shakespeare-Finch \& Copping, 2006; Splevins, Cohen, Bowley, \& Joseph, 2010).
Pada penelitian ini, koping dipilih oleh peneliti untuk menjelaskan post-traumatic growth pada masyarakat terpapar konflik.

Koping didefinisikan sebagai upaya yang dilakukan secara kontinu dalam mengelola tuntutan internal dan eksternal yang dinilai melampaui kemampuannya untuk menghadapi tuntutan tersebut (Lazarus, 1993). Pada teori transaksional yang dikemukakan Lazarus (1993) koping dianggap dapat berubah dari waktu ke waktu dan sesuai dengan situasi menekan yang dihadapi. Teori ini menganggap lebih fleksibel dalam koping akan menghasilkan perilaku yang adaptif. Bolger (dalam Connor-Smith \& Flachsbart, 2007) mendefinisikan koping sebagai aksi kepribadian di bawah tekanan sehingga memengaruhi pemilihan strategi koping. Penilaian individu terhadap situasi menekan yang dianggap bahaya memunculkan koping berfokus pada emosi, sedangkan penilaian terhadap situasi tidak berbahaya memunculkan koping berfokus pada masalah. Kedua bentuk koping tersebut dapat menurunkan stresor dan menghadirkan kesejahteraan psikologis.

Folkman (dalam Bjorklund \& Bee, 2008) menyebutkan terdapat empat tipe koping stres, yaitu: 1) emotional focus coping dimana kontrol diarahkan pada respon emosi terhadap situasi yang menimbulkan stres/tekanan; 2) problem focus coping yang bertujuan untuk mengurangi jumlah situasi stres atau memperluas sumber daya yang dapat menghadapi atau bahkan mengurangi tekanan tersebut; 3) meaning focus coping adalah kemampuan individu menemukan dan mengelola serta menemukan makna dari situasi yang menyebabkan stres; 4) social focus coping, individu melibatkan orang lain dalam mengatasi stres untuk mendapatkan solusi dan memperoleh dukungan emosi. Selain empat tipe koping tersebut, terdapat dua jenis koping lainnya yaitu proactive coping dan religious coping. Proactive coping termasuk dalam tipe keempat 
yaitu kemampuan individu untuk mengenali sumber stres di masa depan sehingga dapat menyiapkan langkah pencegahan terhadap dampak stres. Sementara religious coping, adalah koping dengan menyerahkan diri kepada keyakinan agama yang dimiliki (Bjorklund \& Bee, 2008). Hipotesis dalam kajian ini adalah terdapat hubungan antara koping dengan pertumbuhan pasca-trauma pada masyarakat terpapar konflik.

\section{Metode}

Penelitian ini menggunakan metode penelitian kuantitatif dengan rancangan cross sectional study. Populasi dalam penelitian ini adalah masyarakat penyintas konflik di Aceh Besar. Metode purposive sampling digunakan dalam penelitian ini dengan kriteria untuk sampel yang dipilih adalah mengalami langsung peristiwa tertentu di masa konflik, laki-laki dan perempuan berusia di atas 20 tahun, dapat membaca dan menulis, dan bersedia untuk menjadi responden. Data dikumpulkan menggunakan kuesioner demografi, Post-traumatic Growth Inventory (PTG) (Calhoun \& Tedeschi, 2004), dan Ways of Coping Questionnaire (WCQ) yang dikembangkan oleh Lazarus dan Folkman (dalam Jevnikar, 2008).

Kedua skala yang digunakan telah melalui proses adaptasi bahasa yang mengacu pada Rachmayani \& Ramdhani (2014). Skala PTG terdiri dari 21 item, menggunakan model skala Likert dengan pilihan jawaban 0-5 (tidak meng-

Tabel 1.

Karakteristik Demografi $(\mathrm{N}=55)$

\begin{tabular}{|c|c|c|c|}
\hline & & Jumlah & $(n \%)$ \\
\hline \multirow[t]{5}{*}{ Usia } & $21-30$ & 8 & 14,54 \\
\hline & $31-40$ & 20 & 36,36 \\
\hline & $41-50$ & 13 & 23,63 \\
\hline & $50-60$ & 11 & 20 \\
\hline & $60-70$ & 2 & 3,63 \\
\hline \multirow[t]{2}{*}{ Seks } & Pria & 29 & 52,7 \\
\hline & Wanita & 26 & 47,3 \\
\hline \multirow[t]{6}{*}{ Pendidikan } & Sekolah dasar & 19 & 34,54 \\
\hline & Sekolah Menengah & 11 & 20) \\
\hline & SMA & 17 & 30,91 \\
\hline & Graduate diploma & 3 & 5,45 \\
\hline & Bujangan & 3 & 5,45 \\
\hline & Tidak ada informasi & 2 & 3,64 \\
\hline \multirow[t]{8}{*}{ Pekerjaan } & PNS & 1 & 1,81 \\
\hline & Sektor swasta & 4 & 7,27 \\
\hline & Petani & 35 & 63,64 \\
\hline & Guru & 2 & 3,64 \\
\hline & Pedagang & 5 & 9,1 \\
\hline & Tenaga kerja & 1 & 1,81 \\
\hline & Mahasiswa & 1 & 1,81 \\
\hline & Ibu rumah tangga & 6 & 10,91 \\
\hline \multirow{4}{*}{$\begin{array}{l}\text { Status } \\
\text { pernikahan }\end{array}$} & Menikah & 48 & 87,27 \\
\hline & Duda & 2 & 3,64 \\
\hline & Janda & 1 & 1,81 \\
\hline & Tunggal & 4 & 7,27 \\
\hline Agama & Muslim & 55 & 100 \\
\hline
\end{tabular}


alami perubahan, mengalami perubahan sangat kecil, kecil, sedang, besar, dan sangat besar). Nilai reliabilitas skala PTG ditunjukkan dengan nilai Alpha Cronbach $(\alpha)$ 0,88. Sementara itu skala WCQ memiliki 66 item, menggunakan model Likert dengan pilihan jawaban 0-3 (tidak digunakan, sedikit sekali digunakan, sesekali digunakan, dan sering sekali digunakan). Nilai reliabilitas skala WCQ ditunjukkan dengan nilai Alpha Cronbach $(\alpha) 0,89$. Analisa data dalam penelitian ini menggunakan teknik korelasi product moment, setelah uji asumsi (normalitas dan linieritas) kedua variabel terpenuhi. Untuk normalitas, Skala PTG memiliki nilai KS-Z 0,55, p=0,916, sedangkan skala WCQ memiliki nilai KZ-S 0,76, $\mathrm{p}=0,59$ yang berarti kedua alat ukur terdistribusi normal. Untuk uji linieritas ditunjukkan dengan nilai $\mathrm{F}=1.284, \mathrm{p}=0,326$ yang berarti terdapat hubungan linier antara PTG dan koping.

\section{Hasil}

Penelitian ini melibatkan 55 responden (lakilaki $=52,7 \%$, perempuan $=47,3 \%$ ) untuk mengisi kuesioner. Karakteristik demografi ditunjukkan pada Tabel 1.

Berdasarkan Tabel 1 diketahui bahwa sebagian besar responden adalah dewasa, berusia
30-40 tahun, menikah, dan seluruh responden beragama Islam. Sementara itu, pendidikan terakhir responden terbanyak adalah Sekolah Dasar (34,5\%) dan Sekolah Menengah Atas (30,91\%).

Selain data demografi, penelitian ini juga mengelompokkan peristiwa traumatik yang dialami oleh responden. Pengelompokan tersebut dapat dilihat pada Tabel 2.

Berdasarkan Tabel 2 diketahui bahwa peristiwa traumatik yang dialami laki-laki dan perempuan sedikit berbeda. Laki-laki paling banyak mengalami kekerasan fisik (seperti dipukul dan disiksa) sebanyak 27,6\% serta pemeriksaan dan interogasi $(24,13 \%)$. Sementara perempuan paling banyak menyaksikan pemukulan/penyiksaan (30,8\%) dan interogasi $(23,08 \%)$.

Hasil uji korelasi menunjukkan bahwa terdapat hubungan antara koping dengan pertumbuhan pasca-trauma dengan nilai $r=0,523$ $(p<0,01)$, yang dapat dilihat pada Tabel 3 .

\section{Diskusi}

Hasil penelitian ini membuktikan bahwa koping berhubungan dengan pertumbuhan pascatrauma pada masyarakat Aceh yang terpapar

Tabel 2.

Peristiwa Traumatik saat Konflik $(\mathrm{N}=55)$

\begin{tabular}{lcccc}
\hline \multirow{2}{*}{ Pengalaman } & \multicolumn{2}{c}{ Perempuan } & \multicolumn{2}{c}{ Laki-laki } \\
\cline { 2 - 5 } & $(\mathrm{n}=26)$ & $(\mathrm{n} \%)$ & $(\mathrm{n}=29)$ & $(\mathrm{n} \%)$ \\
\hline Kekerasan fisik (seperti dipukul, di siksa) & 1 & 3,85 & 8 & 27,6 \\
Rumah dibakar & - & - & 1 & 3,45 \\
Diinterogasi & 6 & 23,08 & 7 & 24,13 \\
Melihat pemukulan (anggota keluarga, tetangga, & 8 & 30,8 & 3 & 10,34 \\
teman, dll) & & & & \\
Melihat penembakan & 2 & 7,7 & - & - \\
Rumah hancur & 5 & 19,23 & - & - \\
Melihat penyiksaan & 2 & 7,7 & - & - \\
Diperiksa oleh militer & 1 & 3,85 & 7 & 24,13 \\
Dituduh menjadi separatis & 1 & $3,85)$ & 3 & 10,34 \\
\hline
\end{tabular}


Tabel 3 .

Korelasi Koping dengan Pertumbuhan Pasca-trauma

\begin{tabular}{llll}
\hline Korelasi & & & \\
\hline & & Koping & PTG \\
\hline Koping & Pearson & 1 & $.523^{* *}$ \\
& Sig. (2-tailed) & & .000 \\
& $\mathrm{~N}$ & 55 & 54 \\
\multirow{2}{*}{ PTG } & Korelasi Pearson & $.523^{* *}$ & 1 \\
& Sig. (2-tailed) & .000 & \\
& $\mathrm{~N}$ & 54 & 54 \\
\hline
\end{tabular}

** Korelasi signifikan pada tingkat 0,01 (2-tailed).

konflik. Koping berkontribusi pada pengembangan pandangan positif pada individu secara psikologis setelah mengalami peristiwa traumatik (Folkman \& Moskowitz, 2004). Ai, Tice, Whitsett, Ishisaka, dan Chim (2007) menjelaskan bahwa ada tiga efek positif dari koping setelah kejadian individu yang menghadapi peristiwa traumatik, yaitu: 1) meningkatkan hubungan sosial, seperti keluarga, teman, organisasi pendukung, dan memiliki kepercayaan dalam hubungan sosial; 2) meningkatkan kemampuan dalam berpikir, tegas, pemahaman diri, empati dan menjadi lebih matang; 3) meningkatkan kemampuan mengelola konflik, dapat menemukan solusi, dan peningkatan kemampuan pengaturan diri.

Koping merupakan keseluruhan cara yang dilakukan individu dalam menghadapi dan menenangkan diri dari peristiwa yang menimbulkan tekanan dan melampai batas kemampuan individu, dalam hal ini adalah pengalaman konflik yang dialami. Pada masyarakat yang terpapar konflik baik yang mengalami langsung atau tidak, koping dan fleksibilitasnya dibutuhkan untuk mengelola tekanan dan emosi yang dialami sehingga dapat mencapai pertumbuhan pascatrauma. Pertumbuhan pasca-trauma terjadi sebagai adaptasi terhadap situasi lingkungan negatif yang sangat memengaruhi tingkat stres psikologis dan reaksi psikologis yang tidak menyenangkan.
Penelitian tentang stres dan koping telah menunjukkan bahwa salah satu cara paling efektif yang digunakan individu untuk mengatasi berbagai peristiwa adalah melalui dukungan sosial. Pada penelitian ini, aspek koping dukungan memiliki korelasi dengan PTG ( $\mathrm{r}=0,545)$. Dukungan sosial seperti keluarga dan kerabat tidak hanya berfungsi sebagai ikatan, tetapi bagi korban konflik, dukungan ini dapat mendorong adanya pengungkapan perasaan, pemberian saran dan nasihat, informasi, bantuan materiil dan lainnya membuat perbedaan yang signifikan dalam menghadapi trauma (Ingala, Peters, Hall, \& Box, 2013; Nastasi, Overstreet, \& Summerville, 2011).

Keluarga merupakan salah satu sistem yang keberfungsiannya secara positif dapat menurunkan tekanan keluarga, meningkatkan perkembangan anak, interaksi keluarga yang positif dan daya lenting anggota keluarga pada kondisi terpuruk. Faktor terkait relasi dalam keluarga adalah kohesivitas, keterlibatan dalam keluarga, komunikasi, kemampuan adaptasi atau fleksibilitas, gaya pengasuh dan proses pemecahan masalah (Eagle \& Dowd-Eagle, 2009). Kelekatan dengan orang tua atau anggota keluarga, dan proses interaksi dalam keluarga berkontribusi pada perkembangan penggunaan strategi koping yang konstruktif pada anak (Matheson et al., 2005; Power, 2004; Seiffge-Krenke \& Pakalniskiene, 2011). 
Sebuah penelitian yang dilakukan Rodriguez (2011) menyebutkan bahwa parameter kesejahteraan psikologis yaitu aspek hubungan positif dengan orang lain dan penerimaan diri memiliki hubungan yang signifikan dengan koping konrontif, sementara aspek autonomi dan penguasaan lingkungan berhubungan dengan koping menjauh. Jenis koping, kontrol diri, dan dukungan sosial signifikan terlihat pada aspek autonomi, penguasaan lingkungan, dan penerimaan diri. Selaras dengan hal tersebut, Seligman (dalam Rodriguez, 2011) menyatakan bahwa individu beradaptasi dan tumbuh lebih baik dari kesulitan, kejadian menekan dalam hidup, atau pengalaman traumatik hingga menemukan hal positif dari pribadi melalui keterpurukan.

Namun demikian, di samping dukungan sosial dan keluarga, individu juga diharuskan memiliki kemampuan beradaptasi dan mengendalikan diri. Kontrol diri merupakan upaya penyintas untuk mengelola emosi dan sikapnya terhadap pengalaman traumatik di masa konflik agar tidak memengaruhi kehidupannya saat ini dan masa depan. Menurut kajian Englert, Bertrams, dan Dickhäuser (2011); Schultz, Tallman, dan Altmaier (2010), individu yang mampu mengendalikan diri cenderung lebih mampu bertahan dalam menghadapi kesulitan, sedangkan individu dengan kendali diri rendah, sulit untuk berdamai dengan hal-hal buruk yang terjadi karena tidak mampu mengatur emosi. Penyintas yang mampu mengendalikan diri juga akan mengurangi risiko untuk mengalami gangguan psikologis akibat pengalaman buruk di masa konflik.

Penelitian ini juga mengungkapkan bahwa distancing coping banyak digunakan oleh responden, meskipun dengan kontrol diri yang baik. Distancing coping adalah mengabaikan masalah dengan menolak memikirkan masalah atau mengasumsikan bahwa masalah tidak pernah dialami sebelumnya. Ini dicirikan oleh dorongan untuk melarikan diri dari situasi yang penuh tekanan (Graff, Kaoukis, Vincent, Piotrowski, \& Ediger, 2012). Untuk mendapatkan ketenangan dalam diri, individu bertanggung jawab pada diri dan masalah yang dihadapi. Strategi ini membuat individu cenderung pasif dan memahami yang dialami sebagai nasib yang harus dijalani. Bagi individu yang mengalami dan terpapar konflik cukup lama, internalisasi penerimaan lebih dapat menjalani kondisi ini (Englert et al., 2011; Martz, Bodner, \& Livneh, 2010).

Penerimaan (acceptance) pada masyarakat Aceh yang hidup pada masa konflik tidak dapat dipisahkan dari budaya. Aceh adalah provinsi dengan latar belakang multikultural memainkan peran penting dalam proses adaptasi. Kurdi (2009) menjelaskan bahwa masyarakat Aceh memiliki adat dan budaya yang sangat memengaruhi karakter masyarakat dalam menjalani kehidupan. Keseimbangan, ketenangan di antara orang Aceh didasari pada keyakinan agama. Masyarakat mencari dan menghormati nilai-nilai yang ditetapkan oleh agama atau aturan yang ditetapkan bersama-sama. Dalam Islam, menerima dan memberikan semua untuk Maha kuasa adalah dogma yang terkandung dalam nilai-nilai kehidupan masyarakat. Meskipun koping biasanya dianggap sebagai karakteristik atau kepribadian, penelitian Yeh dan Wang (2000) telah menyarankan bahwa nilainilai budaya yang menekankan hubungan erat dan ikatan keluarga dapat memengaruhi individu dalam menghadapi stres.

Dari penelitian ini, dapat diketahui pertumbuhan pasca trauma berkaitan dengan jenis koping distancing, self control, social support seeking, accepting, planful, dan positive appraisal. Hal ini dapat menjelaskan bahwa dalam menghadapi trauma, pentingnya hubungan baik dengan orang lain akan menghadirkan dukungan. Korban mampu memahami makna teman, kerabat dan keluarga dalam proses adaptasi. 
Selain itu, melihat kemungkinan baru dalam hidup diperoleh dari adanya perencanaan baru setelah mengalami peristiwa traumatik. Penilaian positif juga memungkinkan korban untuk memiliki keterampilan baru dan menumbuhkan keyakinan diri dalam menghadapi masa depan.

Mengacu pada pendekatan fleksibilitas koping, proses pemilihan strategi koping bergantung pada perubahan penilaian terhadap situasi menekan (Kato, 2012). Hal ini juga mungkin dilakukan oleh korban konflik yang berhasil melewati masa sulitnya. Fleksibilitas koping dipahami sebagai kemampuan untuk menghentikan koping yang tidak efektif dan memilih alternatif koping lainnya. Pada pertumbuhan pasca-trauma, koping yang sehat dan konstruktif menjadi faktor pembentuk mental positif untuk kembali menjalani kehidupan setelah mengalami peristiwa buruk. Sistem (keluarga, komunitas, dan organisasi) berperan penting dalam proses pemulihan trauma baik fisik maupun psikologis (Jackson, 2007).

\section{Simpulan}

Hasil penelitian menunjukkan bahwa koping berhubungan dengan pertumbuhan pascatrauma, melalui koefisien korelasi $r=0,523$ $(\mathrm{p}<0,01)$. Hal ini dapat diartikan bahwa masyarakat yang mengalami peristiwa traumatik pada masa konflik dapat mengatasi tekanan psikologis dengan koping konstruktif sehingga mampu beradaptasi melewati kesulitan yang dihadapi dan bertumbuh. Selain itu, jenis koping yang paling berkorelasi dengan pertumbuhan pasca- trauma adalah mencari dukungan sosial $(\mathrm{r}=0,545)$, diikuti oleh distancing $(\mathrm{r}=0,315)$, self control dan accepting $(\mathrm{r}=0,274)$, sedangkan confronting dan escape tidak berhubungan dengan pertumbuhan pasca-trauma. Secara konseptual, beberapa faktor lain berkontribusi pada pertumbuhan psikologis pasca konflik di antaranya kepribadian, spiritualitas, dan optimisme.

\section{Saran}

Berdasarkan hasil dan kesimpulan penelitian, penelitian ini dapat menjadi acuan bagi pihakpihak berkaitan dengan penyelesaian konflik, terutama untuk penyintas, seperti programprogram rehabilitasi sosial sehingga dapat memunculkan pertumbuhan positif pasca konflik. Selain itu, hasil penelitian ini menunjukkan bahwa jenis koping yang berkaitan dengan pertumbuhan pasca trauma adalah jenis koping konstrukstif seperti dukungan sosial, penerimaan, dan kontrol diri, yang semuanya berkaitan dengan sistem kehidupan diluar individu. Oleh karena itu baik penyintas maupun pihak-pihak yang bekerja dalam pemulihan dampak konflik perlu mempertimbangkan unsur modal sosial untuk mendorong pertumbuhan positif setelah mengalami peristiwa traumatik.

Bagi peneliti yang berminat melakukan penelitian dengan topik yang sama, maka dapat menggunakan metode kualitatif untuk memperdalam hasil penelitian, terutama berkaitan dengan dinamika pertumbuhan pasca trauma dan fleksibilitas dalam coping. Selain itu, dapat juga kedua variabel pada penelitian ini dikaitkan dengan konteks budaya.[]

\section{Daftar Pustaka}

Ai, A. L., Tice, T. N., Whitsett, D. D., Ishisaka, T., \& Chim, M. (2007). Postraumatic symptoms and growth of Kosovar war refugees: The influence of hope and cognitive coping. Journal of Positive Psychology, 2(1), 55-65. https://doi.org/10.1080/17439760601069341 
Almedom, A. M. (2005). Resilience, hardiness, sense of coherence, and posttraumatic growth: All paths leading to "light at the end of the tunnel"? Journal of Loss and Trauma, 10(3), 253-265. https://doi.org/10.1080/15325020590928216

Bjorklund, B. R., \& Bee, H. L. (2008). Journey of adulthood (6th ed.). London: Prentice Hall.

Calhoun, L. G., \& Tedeschi, R. G. (2004). Post traumatic growth conceptual foundations.pdf. Psychological Inquiry.

Connor-Smith, J. K., \& Flachsbart, C. (2007). Relations between personality and coping: A meta-analysis. Journal of Personality and Social Psychology, 93(6), 1080-1107. https://doi.org/10.1037/00223514.93.6.1080

Davis, C. G., Wohl, M. J. A., \& Verberg, N. (2007). Profiles of posttraumatic growth following an unjust loss. Death Studies, 31(8), 693-712. https://doi.org/10.1080/07481180701490578

Eagle, J. W., \& Dowd-Eagle, S. E. (2009). Family functioning. In Encyclopedia of Positive Psychology. Oxford, UK: Blackwell Publishing.

Englert, C., Bertrams, A., \& Dickhäuser, O. (2011). Dispositional self-control capacity and trait anxiety as relates to coping styles. Psychology, 2(6), 598-604. https://doi.org/10.4236/psych.2011.26092

Folkman, S., \& Moskowitz, J. T. (2004). Coping: Pitfalls and promise. Annual Review of Psychology, 55(1), 745-774.https://doi.org/10.1146/annurev.psych.55.090902.141456

Gerrish, N., Dyck, M. J., \& Marsh, A. (2009). Post-traumatic growth and bereavement. Mortality, 14(3), 226-244. https://doi.org/10.1080/13576270903017032

Good, Good, Grayman, \& Lakoma. (2006). Psychosocial needs assessment of communities affected by the conflict in the districts of Pidie, Bireuen and Aceh Utara 2006.

Graff, L. A., Kaoukis, G., Vincent, N., Piotrowski, A., \& Ediger, J. (2012). New models of care for psychology in Canada's health services. Canadian Psychology, 53(3), 165-177. https://doi.org/ $10.1037 / \mathrm{a} 0026635$

Ingala, A., Peters, A., Hall, M., \& Box, C. (2013). The role of social support in veterans' college adjustment University of Northern Colorado. International Journal of Humanities and Social Science, 3(11), 14-21.

Jackson, C. A. (2007). Posttraumatic growth: Is there evidence for changing our practice? The Australasian Journal of Disaster and Trauma Studies, 11(1). Retrieved from http://trauma.massey.ac.nz/issues/2007-1/jackson.htm

Jevnikar, L. J. (2008). Ways of coping. Dissertation Abstracts International: Section B: The Sciences and Engineering, 31-34. https://doi.org/10.1097/ACM.0b013e3181e86aa9

Johnson, H., Thompson, A., \& Downs, M. (2009). Non-Western interpreters' experiences of trauma: The protective role of culture following exposure to oppression. Ethnicity and Health, 14(4), 407418. https://doi.org/10.1080/13557850802621449

Kato, T. (2012). Development of the coping flexibility scale: Evidence for the coping flexibility hypothesis. Journal of Counseling Psychology, 59(2), 262-273. https://doi.org/10.1037/ a0027770

Kontras. (2010). Keberatan terhadap usulan dan upaya-upaya pemberian gelar pahlawan nasional RI kepada (alm) H.M. Soeharto. Retrieved from http://kontras.org/aceh/index.php? hal=pers\&id=1161\&tahun $=2010$

Kurdi, M. (2009). Aceh di mata sejarawan: Rekonstruksi sejarah sosial budaya. Banda Aceh: Lembaga Kajian Agama dan Sosial (LKAS). 
Larner, B., \& Blow, A. (2011). A Model of meaning-making coping and growth in combat veterans. Review of General Psychology, 15(3), 187-197. https://doi.org/10.1037/a0024810

Lazarus, R. S. (1993). Coping theory and research: Past, present, and future. Psychosomatic Medicine, 55(3), 234-247. https://doi.org/10.1097/00006842-199305000-00002

Linley, P. A., \& Joseph, S. (2009). Post traumatic growth. In Encyclopaedia of positive psychology (pp. 1-4).

Martz, E., Bodner, T., \& Livneh, H. (2010). Social support and coping as moderators of perceived disability and posttraumatic stress levels among Vietnam theater veterans. Health, 2(4), 332341. https://doi.org/10.4236/health.2010.24050

Matheson, K., Kelly, O., Cole, B., Tannenbaum, B., Dodd, C., \& Anisman, H. (2005). Parental bonding and depressive affect: The mediating role of coping resources. British Journal of Social Psychology, 44(3), 371-395. https://doi.org/10.1348/014466605X37477

Mawarpury, M., \& Faisal, N. (2017). Family resilience factors in conflict region. Jurnal Psikologi Islam, 4(1), 119-125. Retrieved from http://jpi.api-himpsi.org/index.php/jpi/article/view/33

Nastasi, B. K., Overstreet, S., \& Summerville, M. (2011). School-based mental health services in postdisaster contexts: A public health framework. School Psychology International, 32(5), 533-552. https://doi.org/10.1177/0143034311402926

Neria, Y., \& Litz, B. T. (2004). Bereavement by traumatic means: The complex synergy of trauma and grief. Journal of Loss and Trauma, 9(1), 73-87. https://doi.org/10.1080/15325020490255322

Power, T. G. (2004). Stress and coping in childhood: The parents' role. Parenting: Science and Practice , 4(4), 271-317. https://doi.org/10.1207/s15327922par0404_1

Prati, G., \& Pietrantoni, L. (2009). Optimism, social support, and coping strategies as factors contributing to posttraumatic growth: A meta-analysis. Journal of Loss and Trauma, 14(5), 364-388. https://doi.org/10.1080/15325020902724271

Rodriguez, T. J. (2011). Psychological well-being and coping mechanisms of battered women. Asian Journal of Health: Social Descriptive Section, 1(1), 111-127. Retrieved from https://pdfs.semanticscholar.org/dafc/92fbd4acc077587cd6abdda6c503c8fe42c9.pdf

Schultz, J. M., Tallman, B. A., \& Altmaier, E. M. (2010). Pathways to posttraumatic growth: The contributions of forgiveness and importance of religion and spirituality. Psychology of Religion and Spirituality, 2(2), 104-114. https://doi.org/10.1037/a0018454

Seiffge-Krenke, I., \& Pakalniskiene, V. (2011). Who shapes whom in the family: Reciprocal links between autonomy support in the family and parents' and adolescents' coping behaviors. Journal of Youth and Adolescence, 40(8), 983-995. https://doi.org/10.1007/s10964-010-9603-9

Shakespeare-Finch, J., \& Copping, A. (2006). A grounded theory approach to understanding cultural differences in posttraumatic growth. Journal of Loss and Trauma, 11(5), 355-371. https://doi.org/10.1080/15325020600671949

Splevins, K., Cohen, K., Bowley, J., \& Joseph, S. (2010). Theories of posttraumatic growth: Cross-cultural perspectives. Journal of Loss and Trauma, 15(3), 259-277. https://doi.org/10.1080/ 15325020903382111

Svetina, M., \& Nastran, K. (2012). Family relationships and post-traumatic growth in breast cancer patients. Psychiatria Danubina, 24(3), 298-306. https://doi.org/10.1016/j.burns.2014.04.007

Tedeschi, R. G., \& Calhoun, L. G. (2004). Posttraumatic growth: Conceptual foundations and empirical evidence. Psychological Inquiry, 15(1), 1-18. Retrieved from https://www.researchgate.net/ 
publication/280698717_Posttraumatic_Growth_Conceptual_Foundations_and_Empirical_Evid ence

Terry, D. J. (1994). Determinants of coping: The role of stable and situational factors. Journal of Personality and Social Psychology, 66(5), 895-910. Retrieved from http://www.ncbi.nlm.nih.gov/pubmed/8014834

Yeh, C., \& Wang, Y.-W. (2000). Asian American coping attitudes, sources, and practices: Implications for indigenous counseling strategies. Journal of College Student Development, 41, 94-103. Retrieved from https://repository.usfca.edu/soe_fac/31 
This page intentionally left blank. 